\title{
A sterile hydroponic system for characterising root exudates from specific root types and whole-root systems of large crop plants
}

\author{
Akitomo Kawasaki ${ }^{1}$, Shoko Okada ${ }^{2}$, Chunyan Zhang ${ }^{1,6}$, Emmanuel Delhaize ${ }^{1}$, Ulrike Mathesius ${ }^{3}$,
} Alan E. Richardson ${ }^{1}$, Michelle Watt ${ }^{4}$, Matthew Gilliham ${ }^{5}$ and Peter R. Ryan ${ }^{1 *}$

\begin{abstract}
Background: Plant roots release a variety of organic compounds into the soil which alter the physical, chemical and biological properties of the rhizosphere. Root exudates are technically challenging to measure in soil because roots are difficult to access and exudates can be bound by minerals or consumed by microorganisms. Exudates are easier to measure with hydroponically-grown plants but, even here, simple compounds such as sugars and organic acids can be rapidly assimilated by microorganisms. Sterile hydroponic systems avoid this shortcoming but it is very difficult to maintain sterility for long periods especially for larger crop species. As a consequence, studies often use small model species such as Arabidopsis to measure exudates or use seedlings of crop plants which only have immature roots systems.

Results: We developed a simple hydroponic system for cultivating large crop plants in sterile conditions for more than 30 days. Using this system wheat (Triticum aestivum L.) and barley (Hordeum vulgare L.) plants were grown in sterile conditions for 30 days by which time they had reached the six-leaf stage and developed mature root systems with seminal, nodal and lateral roots. To demonstrate the utility of this system we characterized the aluminium-activated exudation of malate from the major types of wheat roots for the first time. We found that all root types measured released malate but the amounts were two-fold greater from the seminal and nodal axile roots compared with the lateral roots. Additionally, we showed that this sterile growth system could be used to collect exudates from intact whole root systems of barley.

Conclusions: We developed a simple hydroponic system that enables cereal plants to be grown in sterile conditions for longer periods than previously recorded. Using this system we measured, for the first time, the aluminiumactivated efflux of malate from the major types of wheat roots. We showed the system can also be used for collecting exudates from intact root systems of 30-day-old barley plants. This hydroponic system can be modified for various purposes. Importantly it enables the study of exudates from crop species with mature root systems.
\end{abstract}

Keywords: Hydroponic, Root exudates, Organic anion, Malate, Aluminium-tolerance, Wheat, Barley, Sterile system, TaALMT1

\footnotetext{
*Correspondence: Peter.Ryan@csiro.au

${ }^{1}$ CSIRO Agriculture and Food, Canberra, ACT, Australia

Full list of author information is available at the end of the article
} 


\section{Background}

Cereal plants are estimated to release approximately $11 \%$ of their net fixed carbon from the roots as rhizodeposits [1]. These deposits include sloughed off border cells and tissues, mucilage, volatile organic molecules and exudates comprised of high and low molecular weight compounds such as sugars, amino acids, phenolics, and organic anions [1-3]. Collectively these compounds modify the rhizosphere and affect the composition and abundance of microorganisms $[4,5]$. Plants are also known to release specific exudate compounds in response to certain environmental stresses. A well-studied example is the release of organic anions from root apices in response to the toxic aluminium $\left(\mathrm{Al}^{3+}\right)$ ions prevalent in acid soils. These anions protect the sensitive root apices by chelating the toxic $\mathrm{Al}^{3+}$ cations in the apoplast of root cells to form less-harmful complexes [6]. In wheat this response is controlled by two genes: TaALMT1 on chromosome 4DL and TaMATE1B on chromosome 4BL. TaALMT1 encodes an anion channel from the aluminium-activated malate transporter family that releases malate anions [7] while TaMATE1B encodes a transporter from the multidrug and toxic compound exudation (MATE) family that releases citrate anions $[8,9]$. Both TaALMT1 and TaMATE1B are constitutively expressed in the root apices of wheat. However, TaALMT1 requires soluble $\mathrm{Al}^{3+}$ cations to activate malate release at low $\mathrm{pH}$, whereas citrate release via TaALMT1B is constitutive and independent of external $\mathrm{pH}$ or $\mathrm{Al}^{3+}$ concentration.

Various methods have been used to collect root exudates and they all have advantages and disadvantages. Exudates can be collected directly from the soil adjacent to roots using suction cups with polymer or ceramic filters [10-12] but it is unclear how the samples collected this way have been modified by microorganisms and, therefore, how well they reflect the compounds released from the roots. Hydroponic systems are convenient for measuring root exudates because they avoid the mechanical damage incurred by removing roots from solid substrates and minimise the microbial degradation of exudates that will occur in soil [13]. Non-sterile hydroponic systems have been successfully employed to measure certain root exudates [14-17], but this becomes more difficult in mature plants because contamination is inevitable. Therefore, the composition and quantity of exudates collected in non-sterile hydroponics growth systems will be affected by microbial activity as well [18].

Sterile hydroponic systems enable root exudates to be measured under controlled conditions. These systems are generally suitable for seedlings or small plants like Arabidopsis that can be grown easily in low-volume wells [19] or sterile glass flasks [20]. It is technically difficult to maintain sterility much beyond the seedling stage with larger plants including many crop species [13, 21]. The reason for this is that the whole plant needs to be fully enclosed to prevent contamination and the roots require larger volumes of hydroponic solution to match their nutrient needs. The solutions need to be renewed periodically and constantly aerated to avoid anaerobic conditions. Both of these requirements increase the risk of contamination. Consequently, most previous studies that have examined the exudates from crop species (e.g. wheat, barley and maize) in sterile conditions have used young plants with immature root systems [22, 23]. The well-characterised organic anion release from Al-resistant wheat plants has only been performed on the seminal roots of young seedlings [7, 9, 24-27] and it is unknown whether the same response occurs in the nodal or lateral roots of older plants. This is an important omission since the composition and quantity of exudates can change with plant age [28] and seminal roots represent a small fraction of the total root system of a mature plant.

A few studies claim to have maintained sterile root systems on wheat and maize plants for several weeks. For instance, Gaume et al. [29, 30] studied root exudates from 18- and 21-day-old maize plants, and Warren $[31,32]$ examined root exudates from 28 -day-old wheat plants. However, it is very unlikely that either of these studies maintained truly sterile root systems over those periods because the shoots were not fully enclosed in sterile chambers. There is a need to develop new methods for analysing exudates from the various root types on mature crop plants under sterile conditions.

We describe a simple and novel hydroponic system that is fully-enclosed and able to maintain crop plants like wheat and barley in sterile conditions until at least the six-leaf stage. Nodal roots and an extensive lateral root system were able to develop during this time. To demonstrate the utility of this method, we characterised the $\mathrm{Al}^{3+}$-activated malate exudation from the seminal, nodal and lateral roots for the first time. We show that this system is also suitable for collecting exudates from the whole intact root systems from similarly-aged sterile plants.

\section{Results}

\section{A system for growing large crop plants under sterile conditions for 30 days}

A hydroponic system was developed for growing cereals such as wheat and barley under axenic conditions for at least 30 days, which was sufficient for plants to develop mature root systems comprising seminal, nodal and lateral roots.

Surface sterilising the seed An important obstacle in maintaining sterility was ensuring the seed was effectively surface-sterilized prior to germination. Using wheat 
grain from different batches or sources several methods were tested which included various combinations of ethanol, bleach and $\mathrm{H}_{2} \mathrm{O}_{2}$ washes, fumigation with chlorine gas and heat treatments. Sterility was easier to achieve if the grain were freshly harvested, clean and visibly free from fungal contamination. Bacteria were relatively easy to control and a single treatment with bleach or chlorine gas was sufficient to eliminate bacterial growth. The fungal spores were more resilient and could not always be controlled with a single treatment with bleach or chlorine gas. Fungal contamination was sometimes detected many days after germination. Endophytes were difficult to eliminate because they were embedded in tissues, but as long as they did not emerge from the rhizodermis and infect the solution they did not affect exudate composition. The most effective procedure for preventing fungal contamination started by imbibing the seed and then using a series of bleach and $\mathrm{H}_{2} \mathrm{O}_{2}$ washes followed by a $50{ }^{\circ} \mathrm{C}$ heat treatment (see "Methods" section). This procedure reduced germination rates by $5-28 \%$, depending on the seed batch, however the sterilized seedlings developed $130-213 \%$ longer seminal roots $(P<0.05)$ than the non-sterilized seeds after 14 days on agar/nutrient plates and the plants later grew well. The method was similarly effective in sterilising barley seed and may be equally useful for sterilising non-cereal species.

Sterile-growth system: The system is fully enclosed and comprised of two joined chambers made from polypropylene containers or jars. The $2 \mathrm{~L}$ upper chamber covered the plant shoot and the $3 \mathrm{~L}$ lower chamber contained the roots and nutrient solution (Fig. 1). Detailed descriptions of the materials required and the procedure for constructing the apparatus is described in the Methods section. These chambers enabled the nutrient solutions to be aerated constantly and renewed regularly without microbial contamination. The polypropylene containers used to construct the system were slightly opaque and reduced the light intensity by $\sim 18 \%$. The light intensity of the growth cabinet was $610 \mu \mathrm{mol}$ photon $\mathrm{m}^{-2} \mathrm{~s}^{-1}$ but the intensity inside the upper chamber was $\sim 500 \mu \mathrm{mol}$ photon $\mathrm{m}^{-2} \mathrm{~s}^{-1}$. However polypropylene containers were most suitable because, apart from being readily available and inexpensive, they withstand autoclaving, are easy to process (drill and glue) and release minimum amounts of organic substances.

Each hydroponic apparatus contained one pre-germinated wheat or barley seedling. The nutrient solutions were changed regularly and sterility was confirmed by periodically plating out a sample of nutrient solution on agar/nutrient plates. No bacterial contamination was detected in any of the samples but fungal contamination developed in two of the 30 systems assembled. The most likely source of this contamination was the seed.

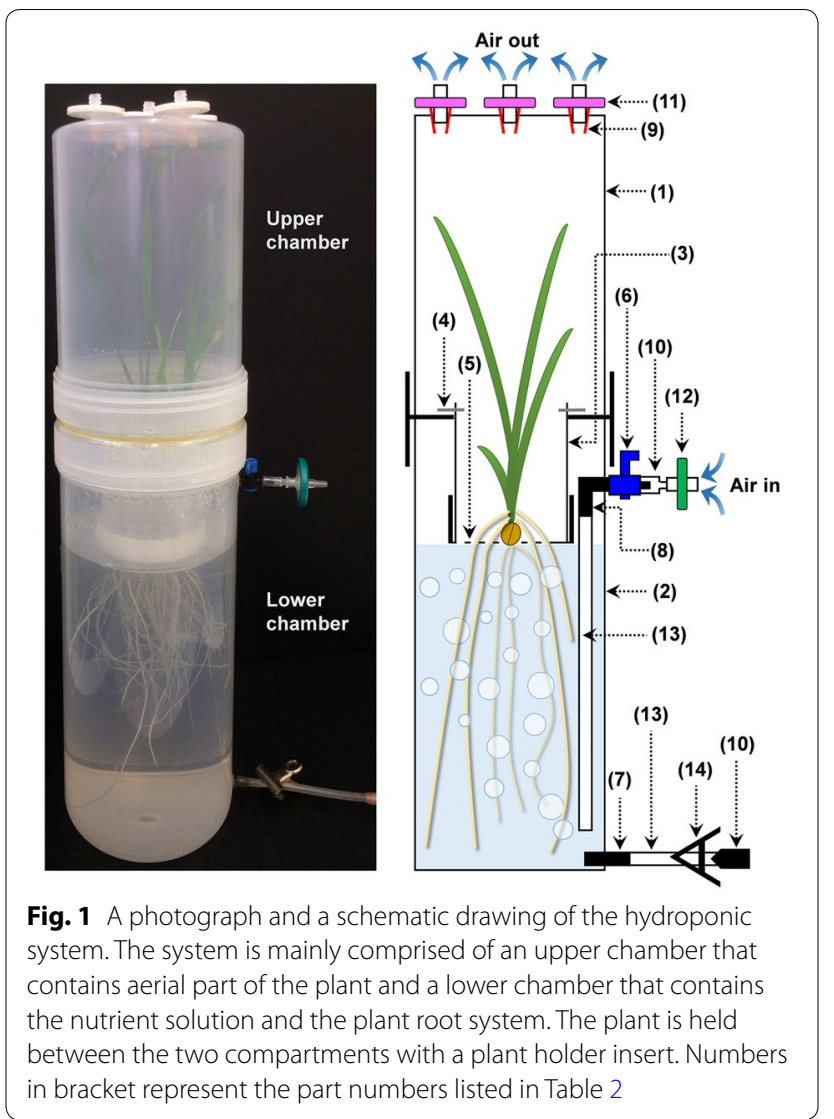

The composition of the nutrient solution is at the discretion of the experimenter. We used a simple low-strength nutrient solution (see "Methods" section) and nutritional status of the plants and $\mathrm{pH}$ of the nutrient solution were monitored. During the preliminary experiments solutions were renewed weekly and while no visual deficiency or toxicity symptoms were detected, tissue analysis at harvest indicated marginal $\mathrm{P}$ deficiency in some plants (Table 1). The solutions were changed more frequently in subsequent experiments. These changes also helped to maintain the solution $\mathrm{pH}$ which tended to decrease between solution changes (from pH 6.0 to 5.0). Changes in $\mathrm{pH}$ can also be minimised by adding a buffering agent or by modifying the composition of the nutrient solution (especially the ratio of ammonium and nitrate) depending on the experimental goals and the species being tested.

Plant growth Wheat plants were typically grown until they were 30 days old. By this time they had reached the six-leaf stage with five to six tillers per plant (Fig. 2a). This is equivalent to the Zadoks scale of 25-26 (Feekes scale 3) [33]. The plants showed a relatively even growth between replicate growth systems with shoot dry weight ranging from 0.64 to $0.81 \mathrm{~g}$ per plant and root dry weight ranging from 0.45 to 0.69 g per plant (Fig. 3a). The two contaminated plants also developed 
Table 1 Elemental wheat shoot tissue

\begin{tabular}{lcl}
\hline Element & Hydroponics & Reference value $^{\mathbf{a}}$ \\
\hline $\mathrm{Al}\left(\mathrm{mg} \mathrm{kg}^{-1}\right)$ & $2.4 \pm 0.5$ & $<200$ \\
$\mathrm{~B}\left(\mathrm{mg} \mathrm{kg}^{-1}\right)$ & $4.4 \pm 1.1$ & $3-25$ \\
$\mathrm{Ca}\left(\% \mathrm{w} \mathrm{w}^{-1}\right)$ & $0.20 \pm 0.01$ & $0.18-0.40$ \\
$\mathrm{Cu}\left(\mathrm{mg} \mathrm{kg}^{-1}\right)$ & $17.7 \pm 0.5$ & $1.3-18.0$ \\
$\mathrm{Fe}\left(\mathrm{mg} \mathrm{kg}^{-1}\right)$ & $63 \pm 2$ & $25-100$ \\
$\mathrm{~K}\left(\% \mathrm{w} \mathrm{w}^{-1}\right)$ & $3.2 \pm 0.1$ & $3.0-3.5$ \\
$\mathrm{Mg}\left(\% \mathrm{w} \mathrm{w}^{-1}\right)$ & $0.08 \pm 0.003$ & $0.05-0.40$ \\
$\mathrm{Mn}\left(\mathrm{mg} \mathrm{kg}^{-1}\right)$ & $93 \pm 6$ & $<700$ \\
$\mathrm{P}\left(\% \mathrm{w} \mathrm{w}^{-1}\right)$ & $0.21 \pm 0.02$ & $0.24-0.70$ \\
$\mathrm{~S}\left(\% \mathrm{w} \mathrm{w}^{-1}\right)$ & $0.35 \pm 0.01$ & $0.28-0.30$ \\
$\mathrm{Zn}\left(\mathrm{mg} \mathrm{kg}^{-1}\right)$ & $102 \pm 4$ & $18-390$ \\
\hline
\end{tabular}

Whole-shoot tissues of sterile hydroponically grown 30-day-old wheat plants were homogenised and elemental content analysed by ICP-MS. Results show the mean $\pm S E(n=10$ plants)

a Reference values were based on the values (wheat at the Feekes scale 3 growth stage) previously reported [68]

biomass within the range. All wheat plants developed five seminal axile roots and between 10 and 15 nodal axile roots per plant (Fig. 2a). Diameters of the seminal and nodal axile roots were similar to one another and significantly greater than the laterals roots $(P<0.001)$ (Fig. 2b). Compared to the similar age plants grown in the non-sterile hydroponic system, the shoot biomass of the sterile plants was generally smaller $(\sim 10$ to $20 \%$ less biomass) probably because they received slightly less light. Nevertheless the plants grown in both conditions developed similar root systems with comparable numbers of nodal and lateral roots (data not shown).

\section{Malate exudation from various root types of Al-resistant wheat}

To demonstrate the utility of this sterile hydroponic system for analysing root exudates, we measured malate efflux from the various root types of mature (30 days old) wheat plants. The wheat cultivar EGA-Burke is resistant to $\mathrm{Al}^{3+}$ toxicity and shows the typical $\mathrm{Al}^{3+}$-activated efflux of malate from the seminal roots. This response has been characterised in detail in previous studies in a range of wheat cultivars $[9,24]$. What was unknown, and the objective of these experiments, is whether the phenotype reported for seminal roots of young seedlings also occurs on the other root types on more mature plants.

After 30 days of growth, the plants were removed from the growth chambers, laid in clean trays with sterile nutrient solution so that the seminal, nodal and lateral roots could be identified. The root apices $(5 \mathrm{~mm})$ excised from these different root types were collected in a tube and used to measure malate efflux in the presence and absence of $60 \mu \mathrm{M} \mathrm{AlCl}_{3}(\mathrm{pH} 4.3)$. In the control treatment (without $\mathrm{Al}^{3+}$ ), malate efflux was $<0.1 \mathrm{nmol}$ ape $\mathrm{x}^{-1} \mathrm{~h}^{-1}$ from all root types (Fig. 4a). In the presence of $\mathrm{Al}^{3+}$, malate efflux increased by 20 to 55 -fold $(P<0.001)$ with the seminal and nodal axile roots releasing more than $2.0 \mathrm{nmol}$ apex ${ }^{-1} \mathrm{~h}^{-1}$ and the lateral roots releasing $\sim 0.40 \mathrm{nmol} \mathrm{apex}{ }^{-1} \mathrm{~h}^{-1}$. Since root diameters of the axile roots (seminals and nodals) were three-fold greater than the lateral roots (Fig. 2b), the surface areas of these

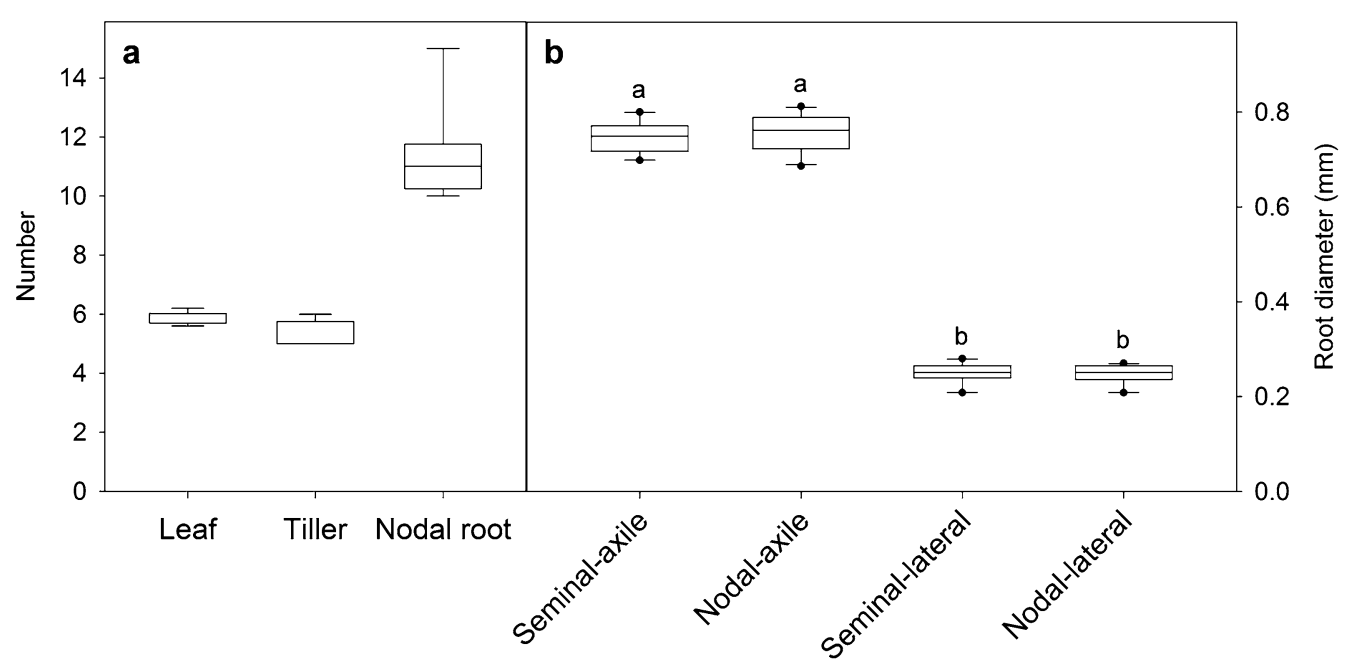

Fig. 2 Wheat growth stage and root diameter in the hydroponic system. Box plots showing a the leaf number (leaf stage), number of tillers and the number of nodal roots developed on the hydroponic plants after 30 days of cultivation, and $\mathbf{b}$ the diameter of each root type of the hydroponically-grown wheat plants $(n=10)$. Different lowercase letters above the plots indicate significant differences as determined by a one-way ANOVA with Holm-Sidak post hoc test $(P<0.001)$ 




Fig. 3 Biomass of hydroponically grown plants. Box plots showing the final shoot and root dry weight of $\mathbf{a}$ wheat $(n=10)$ and $\mathbf{b}$ barley $(n=8)$ after 30 days of cultivation in the sterile hydroponic system



Fig. 4 Malate efflux from the apices of various root types. Data are presented as $\mathbf{a}$ malate efflux per root apex, or $\mathbf{b}$ malate efflux normalized to the tissue surface area. Data are mean \pm SE $(n=3-10)$. Lowercase letters above the bars indicate significant differences $(P<0.05)$ between the root types within the control or $+\mathrm{Al}^{3+}$ treatments, and asterisks above the $+\mathrm{Al}^{3+}$ bars indicate significantly more malate exudation $(P<0.05)$ than the counterpart root type in the control treatment. Equal variance tests failed so data were natural log-transformed prior to two-way ANOVA with Bonferroni post hoc test

tissues will differ by a similar factor. When the fluxes are normalized for surface area, the malate efflux from axile and lateral roots was more similar and varied by two-fold only (Fig. 4b).

\section{Relative expression of TaALMT1 in various root types}

TaALMT1 encodes an anion channel in wheat that facilitates the malate efflux measured above. Once the exudates were collected, RNA was extracted from tissues and TaALMT1 expression was measured using quantitative RT-PCR (qRT-PCR) with two reference genes. TaALMT1 expression was detected in all root types. Since TaALMT1 expression was constitutive and unaffected by $\mathrm{Al}^{3+}$ treatment, data from the control and aluminium treatments were combined. Relative TaALMT1 expression in the axile roots (seminal and nodal) was similar and expression in the lateral roots from the seminal and nodal roots was also similar (Fig. 5). However expression in the laterals was two to three-fold greater than in the axile roots using $\alpha$-tubulin and glyceraldehyde 3-phosphate 


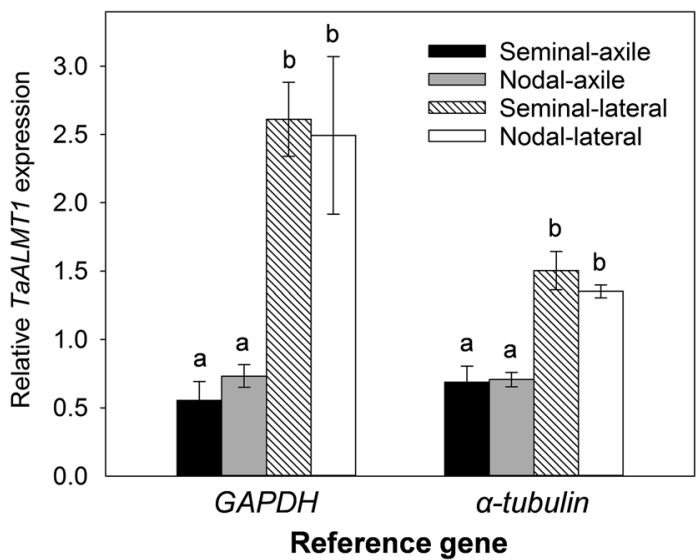

Fig. 5 TAALMT1 expression in various root types. Relative TaALMT1 expression in the various roots of wheat were measured using GAPDH or a-tubulin as reference genes. Data from the control and $+\mathrm{Al}^{3+}$ treatments were combined. Data are mean $\pm \mathrm{SE}(n=6)$. Different lowercase letters indicate significant differences in the gene expression between the root types $(P<0.05)$ within each reference gene used. Equal variance test failed so data were natural log-transformed prior to one-way ANOVA with Holm-Sidak post hoc test

dehydrogenase (GAPDH) as reference genes, respectively.

\section{Organic exudates from whole root systems}

To demonstrate another application of the hydroponic growth technique, we collected the exudates from the whole, intact root system of sterile barley plants. Barley (cv Golden Promise) plants grown in the hydroponic system for 30 days was slightly more vigorous than wheat and showed a greater variation in final root and shoot biomass (Fig. 3b). Roots were rinsed twice with sterile MilliQ water to wash off cell debris and nutrient solution, and root exudates were collected from the whole, intact root system in sterile MilliQ water for $2 \mathrm{~h}$. Exudate compounds were identified with untargeted GC-MS analysis. The original nutrient solution cannot be analysed directly because the mineral salts are incompatible with GC-MS analysis. Furthermore, over time some exudates are likely to be reabsorbed by the roots. While not quantified in detail a total of 95 metabolites were detected among the barley root exudates with the major metabolite groups being amino acids (24 metabolites), organic acids (11 metabolites) or sugars and sugar derivatives (20 metabolites) (Additional file 1: Table S1). The experiment demonstrates another method for collecting exudates from sterile intact roots on more mature plants.

\section{Discussion}

Root exudates are an important means by which plants interact with and control their environment. Hydroponic systems are widely used for studying root exudates even though they lack many of the chemical and mechanical stimuli that could affect growth and exudation [34, 35]. Notwithstanding the artificial nature of hydroponic systems, the literature contains many reports where the physiological processes described in hydroponically grown plants, and even sterile conditions, reflect the same processes occurring in soilgrown plants. Examples include the root exudates associated with aluminium resistance $[9,24,25]$, nutrient stress $[36,37]$ and signalling. For instance, a diverse range of flavonoids released from roots in hydroponics are known to affect signalling, nodulation, plant development, pathogen defence and bacterial quorum sensing in the soil [38], and their roles as inducers of nodulation genes in rhizobia has been demonstrated in vitro using flavonoids collected from the exudates of hydroponically grown plants [39, 40]. Other links have been established between the exudates collected in hydroponics and the microbiome developed around soil-grown plants [41, 42].

Root exudates can be technically difficult to measure and most methods use seedlings or small plants (e.g. Arabidopsis) grown in hydroponic systems [43, 44]. Larger plants pose more challenges especially if sterile conditions are required to avoid microbial degradation of the exudates. Warren $[31,32]$ collected exudates from 4-week old wheat plants but since the shoots were not fully-enclosed it is unlikely that sterility of the roots was maintained. While the nutrient solutions were changed frequently in those experiments (every 2 to 6 days) the roots were maintained in a $250 \mathrm{~mL}$ container which is small considering the root biomass on wheat plants of that age.

The fully-enclosed hydroponic growth system described in this study could maintain sterility until wheat and barley plants were at least 30 days old by which time they had developed mature root systems. Five features of this method are emphasised: (1) Surface-sterilization of the seed is critical to avoid contamination; (2) The system maintained sterility in the chambers despite constant aeration and regular changes in nutrient solutions; (3) The large lower chamber allowed a relatively large volume $(2.2 \mathrm{~L})$ of nutrient solution to be included for root growth. This reduced the number of solution changes required which is important for minimising the risk of contamination; (4) The materials are inexpensive and the assembly is straight forward and uncomplicated; (5) The volume of the chambers can, in principle, be scaled up so that the 
plants can be grown for longer periods than described in this study.

Composition of the nutrient solution and $\mathrm{pH}$ can be adjusted to match the species or experiment requirements. It is important to maintain the $\mathrm{pH}$ stable because it influences the bioavailability of some nutrients [45]. A $\mathrm{pH}$ range of 5.5-6.5 is considered optimum for growing wheat in hydroponics [46]. We used $1 \mathrm{mM}$ MES to buffer the nutrient solution to $\mathrm{pH} 6.0$ but other buffers with different $\mathrm{pKa}$ values are available and the concentration of these can be increased to stabilise $\mathrm{pH}$ as long as growth is not adversely affected [47].

This growth system enabled us to characterise the $\mathrm{Al}^{3+}$-activated malate efflux from specific root types of mature wheat plants. This response is the major mechanism of $\mathrm{Al}^{3+}$ resistance in wheat [25] and although it has been studied in detail for 25 years, all previous reports have used young seedlings with seminal roots only. This has been an important omission because wheat seedlings only develop three to six seminal axile roots which represents a very small proportion of the final root length on mature plants. Nodal roots are probably 10 to 20 -fold more numerous than seminal roots, while lateral roots represent approximately $95 \%$ of total root length in mature cereal plants [48]. Clearly these other roots types play a critical role in accessing water and nutrients $[49,50]$. This sterile growth system enabled us to measure the malate efflux from the four major types of root (seminal axile, nodal axile, seminal lateral and nodal lateral) on 30-day-old wheat plants for the first time. We found that the $\mathrm{Al}^{3+}$-dependent malate release from seminal and nodal roots averaged $2.5 \mathrm{nmol}$ root apex ${ }^{-1} \mathrm{~h}^{-1}$ which was greater than previous reports from seminal roots of 5-day-old seedlings [9, 24]. Lateral roots released less malate than the seminal and nodal axile roots, even after normalising for differences in root surface area (Fig. 4). These results demonstrate that the malate exudation from seminal roots is maintained for many weeks and that similar responses occur on the nodal and lateral roots. This study only investigated malate exudation but the system could be used to measure other exudates from various root types and in different genotypes.

TaALMT1 is constitutively expressed in all four root types which is consistent with rapid activation of malate by $\mathrm{Al}^{3+}$ treatment from all the roots. Interestingly, expression level in lateral roots was significantly greater than the seminal or nodal axile roots even though malate efflux was less from the laterals. Future studies should compare TaALMT1 protein levels since protein/mRNA ratios for a given gene can be vary between tissues [51, 52].

The newly developed hydroponic system was also suitable for collecting exudates from whole-root systems.
We demonstrated this by analysing the exudates from the whole root system of sterile 30-day-old barley plants. We collected root exudates by submerging the roots in $200 \mathrm{~mL}$ of MilliQ water in a $600 \mathrm{~mL}$ beaker with gentle shaking. This volume can be adjusted depending on the root biomass to minimize stress and damage to the tissue. Prolonged treatment to MilliQ water will damage roots because the integrity the root cell membranes can be compromised when $\mathrm{Ca}^{2+}$ is absent from the solution [53]. However the inclusion of too many salts in the solution poses other problems because once they become concentrated after lyophilisation they can interfere with the GC-MS analysis $[54,55]$. As a compromise, we collected the exudates in MilliQ water but only for $2 \mathrm{~h}$. This is shorter than many other studies, some of which collected exudates in ultra-pure water for up to 3 days [56]. Furthermore, the metabolite profile of root exudates collected in water or $0.5 \mathrm{mM} \mathrm{CaCl}_{2}$ was quantitatively and qualitatively similar after short collections periods [57].

Non-targeted GC-MS analysis identified a wide range of compounds with amino acids representing the largest metabolite group. This profile is generally consistent with other root exudate studies of barley and wheat grown in sterile sand [58], moistened filter paper [59] and in hydroponics [31, 32, 60, 61]. Even though exudates were collected over a relatively short period it is possible that the quantity of some compounds might be underestimated using this technique if the roots reabsorb them after being released $[23,31]$. This system would also be useful for investigating specific root-microbe interactions in gnotobiotic conditions.

\section{Conclusions}

We developed a novel hydroponic system that enabled cereal plants to be grown in sterile conditions for longer periods than previously recorded. Wheat and barley plants could be grown till they were 30 days old by which time they had reached the six-leaf stage and developed a mature root system. We demonstrated the advantages of the system for analysing exudates from wheat plants by measuring the $\mathrm{Al}^{3+}$-activated efflux of malate from seminal, nodal and lateral root apices for the first time. We also characterized the root exudates from whole, intact barley root systems. By providing a means of growing larger plants in sterile conditions for longer periods than previously described, this system overcomes the necessity for using smaller model species such as Brachypodium or Arabidopsis as surrogates for crop species.

\section{Methods}

Plant materials and media

The wheat (Triticum aestivum L.) used was the $\mathrm{Al}^{3+}$-resistant cultivar EGA-Burke which possesses the 
Type $\mathrm{V}$ allele of the TaALMT1 gene associated with greater gene expression than $\mathrm{Al}^{3+}$-sensitive cultivars [62]. TaALMT1 encodes the $\mathrm{Al}^{3+}$-activated efflux of malate from the root apices. The barley (Hordeum vulgare L.) cultivar used was Golden Promise.

The hydroponic nutrient solution contained $0.5 \mathrm{mM}$ $\mathrm{CaCl}_{2}, 150 \mu \mathrm{M} \mathrm{MgSO}_{4}, 1 \mathrm{mM} \mathrm{KNO}{ }_{3}, 0.5 \mathrm{mM} \mathrm{NH}_{4} \mathrm{Cl}$,

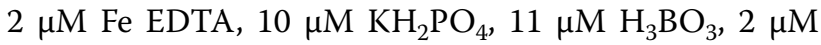
$\mathrm{MnCl}_{2}, 0.35 \mu \mathrm{M} \mathrm{ZnSO}, 0.05 \mu \mathrm{M}\left(\mathrm{NH}_{4}\right)_{6} \mathrm{Mo}_{7} \mathrm{O}_{24}$ and $0.2 \mu \mathrm{M} \mathrm{CuCl}_{2}$. The $\mathrm{pH}$ of the nutrient solution was adjusted to 6.0, and buffered with $1 \mathrm{mM}$ MES. Microbial contamination of seed and nutrient solution was checked by placing them on plates containing $1 \times$ Nutrient Broth (Difco) solidified with $1.5 \%$ agar.

\section{Seed sterilization}

The following procedure for surface-sterilizing the seed was mostly performed in a laminar flow hood. The seeds were first washed with $70 \% \mathrm{EtOH}$ for $1 \mathrm{~min}$ and then imbibed for $7 \mathrm{~h}$ at room temperature (RT) in a $50 \mathrm{~mL}$ screw-top tube half-filled with sterile water plus $0.05 \%$ Tween 20 . The tube was place on a shaker during this period ( $\sim 50 \mathrm{rpm})$. Barley seeds were dehusked prior to this stage. The solution was poured out and the imbibed seed were treated in $20 \%$ household bleach for $10 \mathrm{~min}$ on a shaker followed by multiple rinses with sterile water. The solution was then replaced with $3 \% \mathrm{H}_{2} \mathrm{O}_{2}$ and placed on a shaker for $30 \mathrm{~min}$ [63]. After thorough rinses in sterile water, the tube was half filled with sterile water heated to $50{ }^{\circ} \mathrm{C}$, sealed and placed in a $50{ }^{\circ} \mathrm{C}$ water bath for $10 \mathrm{~min}$ [64]. Sterilized seeds were then placed on Nutrient Broth agar plates, stratified at $4{ }^{\circ} \mathrm{C}$ for $24 \mathrm{~h}$ and allowed to germinate for 2 days at room temperature. Only seedlings with no visible contamination were transferred to the hydroponic system. An additional treatment with systemic fungicide or bactericide could be included if the surface sterilization of seed is insufficient to prevent contamination occurring.

\section{Hydroponic system construct}

The materials required to construct one hydroponic system are listed on Table 2 and shown in Additional file 1: Figs. S2 and S3. The hydroponic system used two containers to create the two main chambers (Fig. 1). The $2 \mathrm{~L}$ upper chamber enclosed the aerial part of the plant (Part \#1, Table 2). The $3 \mathrm{~L}$ lower chamber contains the nutrient solution and plant root system (Part \#2).

Table 2 Materials for constructing one hydroponic system

\begin{tabular}{|c|c|c|c|}
\hline Part \# & Material & Quantity & Supplier \\
\hline 1. & $\begin{array}{l}2 \text { L polypropylene clear plastic container with a screw lid (13 cm diam- } \\
\quad \text { eter } \times 19 \mathrm{~cm} \text { tall) (product code: JARC2000) }\end{array}$ & 1 & The Plastic Man, Mordialloc, VIC, Australia \\
\hline 2. & $\begin{array}{l}3 \text { L polypropylene clear plastic container with a screw lid (13 cm diam- } \\
\text { eter } \times 28.5 \mathrm{~cm} \text { tall) (product code: JARC3000) }\end{array}$ & 1 & \\
\hline 3. & $\begin{array}{l}500 \mathrm{~mL} \text { polypropylene clear tube with screw cap }(6.7 \mathrm{~cm} \text { diameter } \times 15 \mathrm{~cm} \\
\text { tall) (product code: } 75.9922 .812)\end{array}$ & 1 & Sarstedt \\
\hline 4. & Stainless steel wire (1.6 mm diameter), cut into $1 \mathrm{~cm}$ length & 6 & $\mathrm{~N} / \mathrm{A}$ \\
\hline 5. & Polyethylene plastic mesh (3 mm), cut into $6.5 \mathrm{~cm}$ diameter disc & 1 & Menzel Plastic Traders, Melrose Park, SA, Australia \\
\hline 6. & 4 mm Threaded inline tap (product code: 1010452) & 1 & Pope Products, Beverley, SA, Australia \\
\hline 7. & 4 mm Threaded adaptor (product code: 1010013) & 1 & \\
\hline 8. & $\begin{array}{l}4 \mathrm{~mm} \text { Elbow adaptor. One side was trimmed off and the hole was enlarged, so } \\
\text { it can be connected to the Part \#6 (product code: 1010007) }\end{array}$ & 1 & \\
\hline 9. & $\begin{array}{l}\text { Syringe needle. The needle was removed, and only the plastic attachment } \\
\text { base was used }\end{array}$ & 5 & Terumo \\
\hline 10. & $\begin{array}{l}1 \mathrm{~mL} \text { Syringe. Only the first } 2 \mathrm{~cm} \text { of the syringe head was used. The rest was } \\
\text { cut off and removed. This can also be used as a plastic plug when the hole } \\
\text { sealed is sealed }\end{array}$ & 2 & \\
\hline 11. & 0.45 m Nylon syringe filter (autoclavable) (product code: ESF-NY-30-045) & 5 & Kinesis Australia, Redland Bay, QLD, Australia \\
\hline 12. & 0.22 m PES sterile syringe filter (product code: Z359904) & 1 & Millipore \\
\hline 13. & $\begin{array}{l}\text { Medical grade silicone tubing ( } 4 \mathrm{~mm} \text { diameter), cut into } 10 \mathrm{~cm} \text { and } 20 \mathrm{~cm} \\
\text { length }\end{array}$ & 1 Each & $\mathrm{N} / \mathrm{A}$ \\
\hline 14. & Metal bulldog clip & 1 & $\mathrm{~N} / \mathrm{A}$ \\
\hline 15. & Air compressor (35 L min ${ }^{-1}$ capacity), (product code: HAILEA ACO-208) & 1 & Guandong Hailea Group, Guandong, China \\
\hline 16. & Aquarium pump tubing ( $4 \mathrm{~mm}$ diameter) and plastic T-joints for the tubing & As required & N/A \\
\hline 17. & Plastic glue (J-B Weld Plastic Bonder Syringe) & As required & J-B Weld, Sulphur Springs, TX \\
\hline
\end{tabular}


- The lids to these containers (Parts \#1 and \#2) were smoothed with a rotary tool (Dremel), then their upper surfaces scraped to make them rough so the two lids could be glued together with a plastic glue (Part \#17) (Additional file 1: Fig. S4a). This glue is able to bond polypropylene and is resistant to autoclaving. Once the glue was dry, a $7 \mathrm{~cm}$ diameter hole was bored in the centre of the glued lids (Additional file 1: Fig. S4b) which is where the plant holder will sit.

- The plant holder was made from a $500 \mathrm{~mL}$ polypropylene container with lid (Part \#3). The bottom $7 \mathrm{~cm}$ of the tube was removed using a saw, and four small pieces of stainless steel wire (Part \#4) were heated and inserted through the plastic around the cut edge (Additional file 1: Fig. S5a), so that the plant holder could later be suspended upside down in the hole made in the glued lids (Additional file 1: Fig. S6). A hole ( $6 \mathrm{~cm}$ diameter) was bored in the centre of the screw cap of the polypropylene tube (Part \#3). This allowed a disc of plastic mesh (Part \#5) to sit on the inside when the tube was suspended from the glued lids. To secure the mesh in place, two additional pieces of stainless steel wire (Part \#4) were heated and inserted through the side of the lid (Additional file 1: Fig. S5b).

- Five $6 \mathrm{~mm}$ diameter holes were drilled in the bottom of the upper chamber (Part \#1). These later held filters to vent air from the upper chamber. Firstly, syringe needles were obtained and the metal needles removed from their plastic bases by sawing or cutting. These bases (Part \#9) were inserted into the drilled holes and glued in place so that $0.45 \mu \mathrm{m}$ nylon syringe filters (Part \#11) could be later inserted on the outside (Additional file 1: Fig. S7).

- Two $4 \mathrm{~mm}$ holes were drilled on the side of the lower chamber (Part \#2). The first hole was drilled $4 \mathrm{~cm}$ from the top for the air inflow to aerate the solution. The second hole was drilled near the bottom of the chamber and was used for draining when the nutrient solution required changing (see Fig. 1). An inline plastic tap (Part \#6) was screwed into the upper air inlet hole and glued in place. Once dry an elbow adaptor (Part \#8) was firmly attached and glued to the tap on the inner side of the chamber. On the outer side of the chamber, a syringe head (Part \#10) was attached and glued to the inline tap (Part \#6), and this allowed a syringe filter (Part \#12) to be attached for filtering the incoming air. A $20 \mathrm{~cm}$ length of silicon tubing (Part \#13) was attached to the elbow adapter (Part \#8) so that the lower end of the tubing was near the bottom of the chamber. A $4 \mathrm{~mm}$ threaded adaptor (Part \#7) was screwed into the bottom draining hole and glued in place. A $10 \mathrm{~cm}$ length of silicon tubing (Part \#13) was attached to the draining adaptor (Part \#7) at the bottom of the jar. This draining tube was plugged with a plastic plug, which can be made from a $1 \mathrm{~mL}$ syringe head that had the hole was sealed with heat (Part \#10), and clamped with a metal bulldog clip (Part \#14).

- The whole system can be pre-assembled, filled with nutrient solution, and then autoclaved, or each component can be wrapped in foils, autoclaved separately and then assembled in the laminar flow hood.

\section{Hydroponic system setup and plant growth condition}

All sterile setups were performed in a laminar flow cabinet. A $0.22 \mu \mathrm{m}$ sterile nylon syringe filter (Part \#12) was attached to the air inlet tap (Part \#6 and 10 joint) to filter the inward-flowing air (Fig. 1). A series of $0.45 \mu \mathrm{m}$ sterile nylon syringe filters (Part \#11) were then inserted into the adaptors (Part \#9) at the top of the upper chamber (Additional file 1: Fig. S7).

Sterile nutrient solution $(\sim 2.2 \mathrm{~L})$ was added to the lower chamber until the solution just touched the bottom of the plant holder when it was inserted and suspended from the hole in the glued lids (Additional file 1: Fig. S6). The lower chamber was screwed into the glued lids, and using sterile forceps, a surface-sterilized, germinated seedling was carefully placed on the middle of the plastic mesh of the plant holder so that its young roots passed through the mesh and into the nutrient solution. The upper compartment was then screwed into the other side of the glued lids. The compartments and the glued lids were sealed with Parafilm.

Plants were cultivated in a growth cabinet (Conviron, Canada) with a $16 \mathrm{~h}$ day $/ 8 \mathrm{~h}$ night cycle $\left(20{ }^{\circ} \mathrm{C} / 15{ }^{\circ} \mathrm{C}\right)$ and $610 \mu \mathrm{mol}$ photon $\mathrm{m}^{-2} \mathrm{~s}^{-1}$ light intensity. The light intensity was attenuated in the polypropylene containers by $\sim 18 \%$. The lower chamber was not covered so that root development could be easily monitored. However, if it is important that the nutrient solution not be exposed to light the lower chamber can easily be covered with foil or cloth. Typically 12 hydroponic setups were prepared at one time. Aquarium pump tubing (Part \#16) of equal length were attached from the $0.22 \mu \mathrm{m}$ filters to a manifold which was connected to an air compressor (Part \#15). The tube connecting the manifold to the air compressor first passed air through a closed chamber containing activated carbon granules which removed organic volatiles emitted from the pump. The equal length of tubing between the manifold and each inlet port helped ensure the air pressure going to each apparatus was equal. Final aeration rates were $2.9 \mathrm{~L}$ air $\mathrm{min}^{-1}$. 
Nutrient solutions required changing once or twice a week depending on the size of the plants but this will vary depending on the species and the composition of the nutrient media. To change the solutions the aeration tubes were detached from the filters and each apparatus transferred to a laminar flow hood. The solutions were drained into a container via the bottom tube by removing the bulldog clip and the plug (this occurred more easily if the lower chamber is unscrewed slightly). The plug was sterilized with $70 \% \mathrm{EtOH}$ each time it was removed from the tube. Once the solution was drained, the draining tube was plugged and clipped again and the lower chamber unscrewed from the lid. Fresh sterile nutrient solution was added to the lower chamber, by lifting the upper chamber (with the plant holder and plant) for a short time. At each change the $\mathrm{pH}$ of the used solution was measured and sterility checked by plating out a sample on Nutrient Broth agar plates and incubating them at $25^{\circ} \mathrm{C}$ for 3 days.

\section{Plant sampling and root exudate collection}

Wheat and barley plants were harvested after another 28 days of cultivation in the hydroponic system (30 days old from germination). To measure malate exudation from various wheat roots, the upper and the lower chambers were detached, and plants carefully removed from the plant holder and laid on a tray with sterile nutrient solution. The mesh disc remained attached to the roots. The plant was scored for growth stage, tiller number and nodal root number. All axile roots (nodal and seminal) were cut off from the base of the stem and washed in sterile $0.2 \mathrm{mM} \mathrm{CaCl}_{2}$ solution. The root apices $(5 \mathrm{~mm})$ of seminal axile roots, nodal axile roots and the primary lateral roots of seminal and nodal roots were excised with a scalpel and placed in a glass tube. Malate released from these root apices was collected as described previously [24]. Each replicate included five root apices from seminal axile roots, $10-15$ root apices from nodal axile roots, and 30 root apices from each lateral root type. They were washed with $1 \mathrm{~mL}$ of $0.2 \mathrm{mM} \mathrm{CaCl}_{2}$ (pH 4.3) in $5 \mathrm{~mL}$ glass vials sealed with Parafilm by placing the vials on their sides on a platform shaker $(\sim 50 \mathrm{rpm})$ for $30 \mathrm{~min}$. The washing solution was removed, and the root apices were rinsed twice with $1 \mathrm{~mL}$ of $0.2 \mathrm{mM} \mathrm{CaCl}_{2}$ (pH 4.3) (control treatment) or with $0.2 \mathrm{mM} \mathrm{CaCl}_{2}$ with $60 \mu \mathrm{M} \mathrm{AlCl}_{3}$ (pH 4.3) (+ $\mathrm{Al}^{3+}$ treatment). Finally, $1 \mathrm{~mL}$ of $0.2 \mathrm{mM} \mathrm{CaCl}_{2}$ (pH 4.3) or $60 \mu \mathrm{M} \mathrm{AlCl}_{3}$ (in $0.2 \mathrm{mM} \mathrm{CaCl}_{2}$, $\mathrm{pH} 4.3$ ) was added to the vials which were then sealed and returned to the shaker for $2 \mathrm{~h}$. The root exudate solutions were removed and stored at $-20{ }^{\circ} \mathrm{C}$ until the subsequent organic anion analysis. The remaining root apex tissues were stored at $-80{ }^{\circ} \mathrm{C}$ for later RNA extraction.
The diameter of each root type was later measured from stereo microscope images.

To collect exudates from the whole root system of sterile 30-day-old barley plants, the lower chamber of the apparatus was detached and the root system rinsed twice in sterile MilliQ water to wash off the cell debris and nutrient solution. The root system was placed in a $600 \mathrm{~mL}$ glass beaker with $200 \mathrm{~mL}$ of sterile MilliQ water so that the roots were fully immersed (Additional file 1: Fig. S1). The whole apparatus was placed on a gentle shaker and exudates collected for $2 \mathrm{~h}$. The plants were removed and the solutions filtered with a $0.22 \mu \mathrm{m}$ PHENEX RC syringe filter (Phenomenex) and stored at $-20{ }^{\circ} \mathrm{C}$ for subsequent analyses by gas chromatographymass spectrometry (GC-MS).

The shoots and remaining roots were dried in the oven $\left(65^{\circ} \mathrm{C}\right)$ and the dry weights were measured. If elemental analysis of shoots was required, the dried material was acid digested with microwave heating with a MilestoneStart D Microwave Digestion System (Milestone Inc., CT, USA) according to the US EPA method 3015 [65], and the elemental analysis performed with inductively coupled plasma mass spectrometry (ICP-MS) using a Varian Vista-Pro inductively coupled plasma-optical emission spectrometer (Varian Inc., CA, USA) (Analytical Chemistry Group, CSIRO, Australia).

\section{Measurement of malate exudation from root apices}

Malate efflux from the root apices was quantified enzymatically. The procedure was similar to previous descriptions [25] except that $\mathrm{NADH}$ was measured by fluorescence as follows. An aliquot of the exudate solution $(5-10 \mu \mathrm{L})$ was mixed with $50 \mu \mathrm{L}$ of hydrazine buffer (0.5 M glycine, 0.4 M hydrazine, $\mathrm{pH} 9.0$ ), $5 \mu \mathrm{L}$ of $40 \mathrm{mM}$ NAD and placed in a black 96-well plate. Water was added to a final volume of $105 \mu \mathrm{L}$. The initial relative fluorescence unit (RFU) was obtained using a TECAN Infinite M200 PRO microplate reader with $340 \mathrm{~nm}$ excitation wavelength and $440 \mathrm{~nm}$ emission wavelength. Malic dehydrogenase $(0.3 \mu \mathrm{L}, \sim 1.4$ units) (Sigma-Aldrich) was added to each sample and mixed with a pipette and incubated for $30 \mathrm{~min}$ at RT. The RFU readings were measured again using the same settings. The increase in the RFU due to production of $\mathrm{NADH}$ is proportional to the initial amount of malate in the sample. A standard curve generated with a range of malate concentrations was used to estimate malate concentrations in the samples.

\section{GC-MS analysis of root exudates from barley whole root system}

Aliquots $(50 \mathrm{~mL})$ of the barley root exudates were lyophilized and resuspended in $2 \mathrm{~mL}$ of methanol: $\mathrm{H}_{2} \mathrm{O}=1: 1$ (vol:vol), centrifuged at $16,100 \mathrm{~g}$ for $5 \mathrm{~min}$ to remove 
solid matter, and $400 \mu \mathrm{L}$ of the resulting supernatant was dried down in $2 \mathrm{~mL}$ amber glass vials with inserts using a MiVac centrifugal concentrator (SP Scientific). Dried samples were methoxymated with $15 \mu \mathrm{L}$ of $20 \mathrm{mg} \mathrm{mL}^{-1}$ methoxyamine hydrochloride (Sigma-Aldrich) in pyridine at $37^{\circ} \mathrm{C}$ for $90 \mathrm{~min}$, followed by silylation with $15 \mu \mathrm{L}$ of $\mathrm{N}$-methyl- $N$-(trimethylsilyl)-trifluoroacetamide (GC derivatization grade, Sigma-Aldrich) at $37{ }^{\circ} \mathrm{C}$ for $30 \mathrm{~min}$. Derivatised samples were analysed by GC-MS on a DB5 column $(0.25 \mathrm{~mm}$ internal diameter, $1 \mu \mathrm{m}$ film thickness, $30 \mathrm{~m}$ length) with a Shimadzu TQ8050 GC-MS/MS (Shimadzu Corp.) in multiple reaction monitoring (MRM) mode. Sample $(1 \mu \mathrm{L})$ was injected in split mode at a 1:10 ratio into the inlet that was heated to $280{ }^{\circ} \mathrm{C}$, and helium was used as the carrier gas at a constant linear velocity of $39 \mathrm{~cm} \mathrm{~s}^{-1}$ with a purge flow rate of $5 \mathrm{~mL} \mathrm{~min}^{-1}$. The GC oven was held at $100{ }^{\circ} \mathrm{C}$ for $4 \mathrm{~min}$, followed by a $10{ }^{\circ} \mathrm{C}$ $\mathrm{min}^{-1}$ ramp to $320{ }^{\circ} \mathrm{C}$, which was held for $11 \mathrm{~min}$. The MS interface and ion source temperatures were held at $280{ }^{\circ} \mathrm{C}$ and $200{ }^{\circ} \mathrm{C}$, respectively, and the ionisation voltage was $70 \mathrm{eV}$. Metabolites were detected using the Smart Metabolites Database (Shimadzu Corp.), which contains MRM parameters for optimal transitions and retention time window for 467 metabolites. Detected metabolites in MRM mode were cross-checked by analysing the derivatised samples in full scan mode with the mass measurement range between 45 and $600 \mathrm{~m} / \mathrm{z}$, and mass spectrum of peaks of interest searched against NIST 14 (National Institute of Standards and Technology, U.S. Department of Commerce) and the Golm metabolome database (http://gmd.mpimp-golm.mpg.de/).

\section{RNA extraction and quantitative Real-Time PCR}

RNA was extracted from the wheat root apices using the RNeasy Plant Mini Kit (QIAGEN) according to the manufacturer's protocol, which included a DNase step. cDNA was synthesized using SuperScript IV Reverse Transcriptase (Thermo Fisher Scientific) with Oligo $(\mathrm{dT})_{20}$ primer (Thermo Fisher Scientific). Gene expression of TaALMT1 (malate anion channel) was analysed with qRT-PCR. Primers CGTGAAAGCAGCGGAAAGCC (forward) and CCCTCGACTCACGGTACTAACAAC G (reverse) [66] were used to amplify the TaALMT1 transcript. GAPDH and $\alpha$-tubulin were used as the reference genes, and these were amplified with TCAGAC TCCTCCTTGATAGC (forward) and GTTGAGGGT TTGATGACCAC (reverse) primer set [67], and TCC AGTTCGTCGACTGGTGC (forward) and TCCTCG TAGTCCTTCTCCAG (reverse) primer set [8] respectively. qRT-PCR was performed with a Lightcycler ${ }^{\circledR} 480$ Instrument II (Roche), in a $10 \mu \mathrm{L}$ reaction mix consisted of $5 \mu \mathrm{L}$ SsoAdvanced ${ }^{\mathrm{TM}}$ Universal SYBR ${ }^{\circledR}$ Green Supermix (Bio-Rad), 5 pmol each of forward and reverse primers and $10 \mathrm{ng}$ of the template cDNA. The PCR conditions were $95{ }^{\circ} \mathrm{C}$ for $5 \mathrm{~min}$, followed by 45 cycles of $95^{\circ} \mathrm{C}$ for $15 \mathrm{~s}, 55^{\circ} \mathrm{C}$ for $20 \mathrm{~s}$ and $72{ }^{\circ} \mathrm{C}$ for $30 \mathrm{~s}$ (+ plate read). Meltcurve analysis was performed after the amplification step by increasing the temperature from 65 to $95{ }^{\circ} \mathrm{C}\left(0.5{ }^{\circ} \mathrm{C}\right.$ increment, $5 \mathrm{~s}$ per step) (+ plate read).

\section{Statistical analysis}

One-way analysis of variance (ANOVA) and two-way ANOVA were performed with SigmaPlot 13.0 package (Systat Software Inc., San Jose, CA). When the data showed non-homogeneous variances using the BrownForsythe test, the data were transformed using the natural logarithms prior to the statistical analysis. Post hoc analysis were performed with either Bonferroni or HolmSidak methods depending on the data set.

\section{Additional file}

Additional file 1: Table S1. Identity of exudates collected from the whole root system of 30-day-old sterile-grown barley plants. Figure S1. Method for collecting exudates from the whole root system of sterile-grown barley plants. Figure S2. A photograph of some components used for constructing the sterile hydroponic system. Figure S3. Photographs of other components used for constructing the sterile hydroponic system. Figure S4. Connector of the upper and the lower chambers of the hydroponic system. Figure S5. Details of the plant holder. Figure S6. A plant holder suspended from the glued lids. Figure S7. View from above of the upper chamber and the air vents of the hydroponic system.

\section{Authors' contributions}

AK designed the hydroponic system, performed most of the experiments and analysed the data. PRR was the project leader and helped with most of the experiments. AK and PRR were the major contributors in drafting the manuscript. SO performed the GC-MS analysis and helped in drafting the manuscript. CZ helped with RNA extraction and GRT-PCR. ED provided the wheat germplasm and helped draft the manuscript. UM, AER, MW and MG helped prepare the grant and the manuscript. All authors read and approved the final manuscript.

\section{Author details}

${ }^{1}$ CSIRO Agriculture and Food, Canberra, ACT, Australia. ${ }^{2}$ CSIRO Land and Water, Canberra, ACT, Australia. ${ }^{3}$ Division of Plant Science, Research School of Biology, Australian National University, Canberra, ACT, Australia. ${ }^{4}$ Forschungszentrum Jülich $\mathrm{GmbH}$, Jülich, Germany. ${ }^{5}$ ARC Centre of Excellence in Plant Energy Biology, School of Agriculture, Food and Wine, Waite Research Institute, University of Adelaide, Glen Osmond, SA, Australia. ${ }^{6}$ Present Address: College of Life Science, China West Normal University, Nanchong, Sichuan, China.

\section{Acknowledgements}

We thank Deying Zeng for assisting with setting up the hydroponic system.

\section{Competing interests}

The authors declare that they have no competing interests.

\section{Availability of data and material}

All data generated or analysed during this study are included in this published article [and its supplementary information files]. The datasets used and/or analysed during the current study are available from the corresponding author on reasonable request. 


\section{Consent for publication}

All authors have read this paper and consent to publication.

\section{Ethics approval and consent to participate}

Not applicable.

\section{Funding}

This study is funded by CSIRO OCE postdoctoral fellowship to AK.

\section{Publisher's Note}

Springer Nature remains neutral with regard to jurisdictional claims in published maps and institutional affiliations.

Received: 26 June 2018 Accepted: 10 December 2018 Published online: 20 December 2018

\section{References}

1. Jones DL, Nguyen C, Finlay RD. Carbon flow in the rhizosphere: carbon trading at the soil-root interface. Plant Soil. 2009;321(1-2):5-33.

2. Dennis PG, Miller AJ, Hirsch PR. Are root exudates more important than other sources of rhizodeposits in structuring rhizosphere bacterial communities? FEMS Microbiol Ecol. 2010;72(3):313-27.

3. Nguyen C. Rhizodeposition of organic C by plants: mechanisms and controls. Agronomie. 2003;23(5-6):375-96.

4. Hartmann A, Schmid M, van Tuinen D, Berg G. Plant-driven selection of microbes. Plant Soil. 2009:321(1-2):235-57.

5. Sasse J, Martinoia E, Northen T. Feed your friends: do plant exudates shape the root microbiome? Trends Plant Sci. 2018;23(1):25-41.

6. Ryan PR, Tyerman SD, Sasaki T, Furuichi T, Yamamoto Y, Zhang WH, Delhaize E. The identification of aluminium-resistance genes provides opportunities for enhancing crop production on acid soils. J Exp Bot. 2011;62(1):9-20.

7. Sasaki T, Yamamoto Y, Ezaki B, Katsuhara M, Ahn SJ, Ryan PR, Delhaize E, Matsumoto $\mathrm{H}$. A wheat gene encoding an aluminum-activated malate transporter. Plant J. 2004;37(5):645-53.

8. Tovkach A, Ryan PR, Richardson AE, Lewis DC, Rathjen TM, Ramesh S, Tyerman SD, Delhaize E. Transposon-mediated alteration of TaMATE1B expression in wheat confers constitutive citrate efflux from root apices. Plant Physiol. 2013;161(2):880-92.

9. Ryan PR, Raman H, Gupta S, Horst WJ, Delhaize E. A second mechanism for aluminum resistance in wheat relies on the constitutive efflux of citrate from roots. Plant Physiol. 2009;149(1):340-51.

10. Shen J, Hoffland E. In situ sampling of small volumes of soil solution using modified micro-suction cups. Plant Soil. 2007;292(1):161-9.

11. Dessureault-Rompre J, Nowack B, Schulin R, Luster J. Modified micro suction cup/rhizobox approach for the in situ detection of organic acids in rhizosphere soil solution. Plant Soil. 2006;286(1-2):99-107.

12. Oburger E, Dell'mour M, Hann S, Wieshammer G, Puschenreiter M, Wenzel WW. Evaluation of a novel tool for sampling root exudates from soilgrown plants compared to conventional techniques. Environ Exp Bot. 2013:87:235-47.

13. Vranova V, Rejsek K, Skene KR, Janous D, Formanek P. Methods of collection of plant root exudates in relation to plant metabolism and purpose: a review. J Plant Nutr Soil Sci. 2013;176(2):175-99.

14. Luo Q, Wang SY, Sun LN, Wang H. Metabolic profiling of root exudates from two ecotypes of Sedum alfredii treated with Pb based on GC-MS. Sci Rep. 2017;7:39878.

15. Guo HP, Feng X, Hong CT, Chen HM, Zeng FR, Zheng BS, Jiang DA. Malate secretion from the root system is an important reason for higher resistance of Miscanthus sacchariflorus to cadmium. Physiol Plant. 2017;159(3):340-53.

16. Yokosho K, Yamaji N, Ueno D, Mitani N, Ma JF. OsFRDL1 is a citrate transporter required for efficient translocation of iron in rice. Plant Physiol. 2009;149(1):297-305.

17. Yokosho K, Yamaji N, Ma JF. An Al-inducible MATE gene is involved in external detoxification of Al in rice. Plant J. 2011:68(6):1061-9.
18. Kuijken RCP, Snel JFH, Heddes MM, Bouwmeester HJ, Marcelis LFM. The importance of a sterile rhizosphere when phenotyping for root exudation. Plant Soil. 2015;387(1-2):131-42.

19. Badri DV, Loyola-Vargas VM, Broeckling CD, De-la-Pena C, Jasinski M, Santelia D, Martinoia E, Sumner LW, Banta LM, Stermitz F, et al. Altered profile of secondary metabolites in the root exudates of Arabidopsis ATP-binding cassette transporter mutants. Plant Physiol. 2008;146(2):762-71.

20. Strehmel N, Bottcher C, Schmidt S, Scheel D. Profiling of secondary metabolites in root exudates of Arabidopsis thaliana. Phytochemistry. 2014;108:35-46.

21. Jones DL. Organic acids in the rhizosphere-a critical review. Plant Soil. 1998;205(1):25-44.

22. Jones DL, Darrah PR. Influx and efflux of organic-acids across the soil-root interface of Zea mays L. and its implications in rhizosphere C flow. Plant Soil. 1995;173(1):103-9.

23. Jones DL, Darrah PR. Amino-acid influx at the soil-root interface of Zea mays $\mathrm{L}$. and its implications in the rhizosphere. Plant Soil. 1994;163(1):1-12.

24. Ryan PR, Delhaize E, Randall PJ. Characterization of Al-stimulated efflux of malate from the apices of Al-tolerant wheat roots. Planta. 1995;196(1):103-10.

25. Delhaize E, Ryan PR, Randall PJ. Aluminum tolerance in wheat (Triticum aestivum L.) (II. Aluminum-stimulated excretion of malic acid from root apices). Plant Physiol. 1993;103(3):695-702.

26. Zhou G, Pereira JF, Delhaize E, Zhou M, Magalhaes JV, Ryan PR. Enhancing the aluminium tolerance of barley by expressing the citrate transporter genes SbMATE and FRD3. J Exp Bot. 2014;65(9):2381-90.

27. Gruber BD, Ryan PR, Richardson AE, Tyerman SD, Ramesh S, Hebb DM, Howitt SM, Delhaize E. HvALMT1 from barley is involved in the transport of organic anions. J Exp Bot. 2010;61(5):1455-67.

28. Bacilio-Jiménez M, Aguilar-Flores S, Ventura-Zapata E, Pérez-Campos E, Bouquelet S, Zenteno E. Chemical characterization of root exudates from rice (Oryza sativa) and their effects on the chemotactic response of endophytic bacteria. Plant Soil. 2003;249(2):271-7.

29. Gaume A, Machler F, De Leon C, Narro L, Frossard E. Low-P tolerance by maize (Zea mays L.) genotypes: significance of root growth, and organic acids and acid phosphatase root exudation. Plant Soil. 2001:228(2):253-64

30. Gaume A, Machler F, Frossard E. Aluminum resistance in two cultivars of Zea mays L.: root exudation of organic acids and influence of phosphorus nutrition. Plant Soil. 2001;234(1):73-81.

31. Warren CR. Wheat roots efflux a diverse array of organic N compounds and are highly proficient at their recapture. Plant Soil. 2015;397(1-2):147-62.

32. Warren CR. Simultaneous efflux and uptake of metabolites by roots of wheat. Plant Soil. 2016;406(1-2):359-74.

33. Zadoks JC, Chang TT, Konzak CF. A decimal code for the growth stages of cereals. Weed Res. 1974;14(6):415-21.

34. Badri DV, Vivanco JM. Regulation and function of root exudates. Plant Cell Environ. 2009;32(6):666-81

35. Oburger $E$, Jones DL. Sampling root exudates-mission impossible? Rhizosphere. 2018;6:116-133

36. Carvalhais LC, Dennis PG, Fedoseyenko D, Hajirezaei MR, Borriss R, von Wiren N. Root exudation of sugars, amino acids, and organic acids by maize as affected by nitrogen, phosphorus, potassium, and iron deficiency. J Plant Nutr Soil Sci. 2011;174(1):3-11.

37. Bowsher AW, Ali R, Harding SA, Tsai C-J, Donovan LA. Evolutionary divergences in root exudate composition among ecologically-contrasting Helianthus species. PLoS One. 2016;11(1):e0148280.

38. Hassan S, Mathesius U. The role of flavonoids in root-rhizosphere signalling: opportunities and challenges for improving plant-microbe interactions. J Exp Bot. 2012;63(9):3429-44.

39. Peters NK, Frost JW, Long SR. A plant flavone, luteolin, induces expression of Rhizobium meliloti nodulation genes. Science. 1986;233(4767):977-80.

40. Redmond JW, Batley M, Djordjevic MA, Innes RW, Kuempel PL, Rolfe BG. Flavones induce expression of nodulation genes in Rhizobium. Nature 1986;323(6089):632-5.

41. Kawasaki A, Donn S, Ryan PR, Mathesius U, Devilla R, Jones A, Watt M. Microbiome and exudates of the root and rhizosphere of Brachypodium distachyon, a model for wheat. PLoS One. 2016;11(10):e0164533. 
42. Badri DV, Quintana N, El Kassis EG, Kim HK, Choi YH, Sugiyama A, Verpoorte R, Martinoia E, Manter DK, Vivanco JM. An ABC transporter mutation alters root exudation of phytochemicals that provoke an overhaul of natural soil microbiota. Plant Physiol. 2009;151(4):2006-17.

43. Conn SJ, Hocking B, Dayod M, Xu B, Athman A, Henderson S, Aukett L, Conn V, Shearer MK, Fuentes S, et al. Protocol: optimising hydroponic growth systems for nutritional and physiological analysis of Arabidopsis thaliana and other plants. Plant Methods. 2013;9:4.

44. Schlesier B, Breton F, Mock HP. A hydroponic culture system for growing Arabidopsis thaliana plantlets under sterile conditions. Plant Mol Biol Rep. 2003;21(4):449-56.

45. Hinsinger $P$, Plassard C, Tang CX, Jaillard B. Origins of root-mediated $\mathrm{pH}$ changes in the rhizosphere and their responses to environmental constraints: a review. Plant Soil. 2003:248(1-2):43-59.

46. Islam AKMS, Edwards DG, Asher CJ. pH optima for crop growth. Plant Soil. 1980;54(3):339-57.

47. Kagenishi T, Yokawa K, Baluška F. MES buffer affects Arabidopsis root apex zonation and root growth by suppressing superoxide generation in root apex. Front Plant Sci. 2016;7:79.

48. Ito K, Tanakamaru K, Morita S, Abe J, Inanaga S. Lateral root development, including responses to soil drying, of maize (Zea mays) and wheat (Triticum aestivum) seminal roots. Physiol Plant. 2006;127(2):260-7.

49. Ahmed MA, Zarebanadkouki M, Kaestner A, Carminati A. Measurements of water uptake of maize roots: the key function of lateral roots. Plant Soil. 2016:398(1):59-77.

50. Zhu JM, Lynch JP. The contribution of lateral rooting to phosphorus acquisition efficiency in maize (Zea mays) seedlings. Funct Plant Biol. 2004;31(10):949-58.

51. Silva GM, Vogel C. Quantifying gene expression: the importance of being subtle. Mol Syst Biol. 2016;12(10):885.

52. Vogel C, Marcotte EM. Insights into the regulation of protein abundance from proteomic and transcriptomic analyses. Nat Rev Genet. 2012;13(4):227-32.

53. Hanson JB. The functions of calcium in plant nutrition. In: Tinker PB, Läuchli A, editors. Advances in plant nutrition, vol. 1. New York: Praeger Scientific; 1984. p. 149-208.

54. Neumann G, Römheld V. The release of root exudates as affected by the plant physiological status. In: Pinton R, Varanini Z, Nannipieri P, editors. The rhizosphere: biochemistry and organic substances at the soil-plant interface. 2nd ed. Boca Raton: CRC Press; 2007. p. 23-72.
55. Rood D. Gas chromatography problem solving and troubleshooting. J Chromatogr Sci. 1996;34(6):305-6.

56. Chaparro JM, Badri DV, Bakker MG, Sugiyama A, Manter DK, Vivanco JM. Root exudation of phytochemicals in Arabidopsis follows specific patterns that are developmentally programmed and correlate with soil microbial functions. PLoS One. 2013;8(2):e55731.

57. Tawaraya K, Horie R, Shinano T, Wagatsuma T, Saito K, Oikawa A. Metabolite profiling of soybean root exudates under phosphorus deficiency. Soil Sci Plant Nutr. 2014;60(5):679-94.

58. Vancura V. Root exudates of plants. I. Analysis of root exudates of barley and wheat in their initial phases of growth. Plant Soil. 1964;21:231-48.

59. Kovacs MF. Identification of aliphatic and aromatic acids in root and seed exudates of peas, cotton, and barley. Plant Soil. 1971;34(2):441-51.

60. Fan TWM, Lane AN, Shenker M, Bartley JP, Crowley D, Higashi RM. Comprehensive chemical profiling of gramineous plant root exudates using high-resolution NMR and MS. Phytochemistry. 2001;57(2):209-21.

61. Fan TWM, Lane AN, Pedler J, Crowley D, Higashi RM. Comprehensive analysis of organic ligands in whole root exudates using nuclear magnetic resonance and gas chromatography-mass spectrometry. Anal Biochem. 1997:251(1):57-68.

62. Sasaki T, Ryan PR, Delhaize E, Hebb DM, Ogihara Y, Kawaura K, Noda K, Kojima T, Toyoda A, Matsumoto $\mathrm{H}$, et al. Sequence upstream of the wheat (Triticum aestivum L.) ALMT1 gene and its relationship to aluminum resistance. Plant Cell Physiol. 2006;47(10):1343-54.

63. Barampuram S, Allen G, Krasnyanski S. Effect of various sterilization procedures on the in vitro germination of cotton seeds. Plant Cell Tissue Organ Cult. 2014;118(1):179-85.

64. Watts JE, Devilliers OT, Watts L. Sterilization of wheat seeds for tissue culture purposes. S Afr J Bot. 1993:59(6):641-2.

65. US-EPA: Method 3015A (SW-846). Microwave assisted acid digestion of aqueous samples and extracts, revision 1, Washington; 2007.

66. Delhaize E, Ryan PR, Hebb DM, Yamamoto Y, Sasaki T, Matsumoto H. Engineering high-level aluminum tolerance in barley with the ALMT1 gene. Proc Natl Acad Sci USA. 2004;101(42):15249-54.

67. Zhou GF, Delhaize E, Zhou MX, Ryan PR. The barley MATE gene, HVAACT1, increases citrate efflux and $\mathrm{Al}^{3+}$ tolerance when expressed in wheat and barley. Ann Bot. 2013;112(3):603-12.

68. Reuter DJ, Robinson JB. Plant analysis: an interpretation manual. Melbourne: Inkata Press; 1986.
Ready to submit your research? Choose BMC and benefit from:

- fast, convenient online submission

- thorough peer review by experienced researchers in your field

- rapid publication on acceptance

- support for research data, including large and complex data types

- gold Open Access which fosters wider collaboration and increased citations

- maximum visibility for your research: over $100 \mathrm{M}$ website views per year

At BMC, research is always in progress.

Learn more biomedcentral.com/submissions 